\title{
Comunicação
}

[Communication]

\section{Enterotoxemia em bovino}

[Bovine enterotoxaemia ]

F.C.F. Lobato, R.A. Assis, V.L.V.Abreu, M.F. Souza Jr., C.G.R.D. Lima, F.M. Salvarani

\author{
Escola de Veterinária - UFMG \\ Caixa Postal 567 \\ 30123-970 - Belo Horizonte, MG
}

Clostridium perfringens é classificado em cinco tipos (A-E), com base na produção de quatro principais toxinas, denominadas alfa, beta, épsilon e iota. A enterotoxemia produzida por $C$. perfringens tipo $\mathrm{D}$ ocorre em ovinos, caprinos e bovinos, acomete principalmente animais entre três dias e seis meses de idade (Lobato et al., 2000), embora tenha sido descrita em animais adultos (Sigurdarson eThorsteinsson, 1990; Silveira et al., 1995). A doença está relacionada principalmente à ação necrosante e letal da toxina épsilon secretada pelos tipos $\mathrm{B}$ e D, produzida inicialmente como uma prototoxina, que é ativada pela tripsina ou por toxinas secundárias de $C$. perfringens (Minami et al., 1997). Fatores que alteram o ambiente intestinal, como níveis elevados de carboidratos, dietas ricas em proteína e pastagens luxuriantes, podem resultar em abundante crescimento de $C$. perfringens e produção de toxinas (Kriek et al., 1994).

Este trabalho teve por objetivo descrever um caso de enterotoxemia bovina por $C$. perfringens tipo D em Morro da Garça, Minas Gerais.

Em um lote de 540 vacas em lactação, da raça Girolanda, em regime semi-intensivo, morreram cinco animais no intervalo de um a três dias. Segundo o médico veterinário, esses animais apresentavam fezes mais fluídas e escuras, dificuldade de locomoção, inicialmente afetando os membros posteriores, seguindo-se de decúbito lateral e morte. Os animais eram alimentados com silagem de milho, polpa cítrica, caroço de algodão, concentrado protéico, uréia e mistura mineral. Em uma determinada época, houve a substituição da polpa cítrica pela casquinha de soja sem que houvesse a adaptação dos animais. A casquinha de soja foi fornecida por aproximadamente 20 dias. Os animais eram vacinados contra febre aftosa, raiva, rinotraqueíte infecciosa bovina e diarréia viral bovina e vermifugados no pré-parto. A vacinação contra clostridioses era feita na fase de recria, do terceiro ao $12^{\circ}$ mês de idade.

Realizou-se necropsia em um animal com menos de duas horas após a morte, encontrando-se alterações ao longo do intestino delgado, principalmente em sua porção mais distal, caracterizadas pela presença de petéquias, edema e conteúdo amarelo-escuro. Amostra do conteúdo intestinal foi remetida sob refrigeração ao laboratório. Esfregaços do conteúdo intestinal foram confeccionados e corados pelo Gram. O material foi inoculado em ágar sangue $\mathrm{e}$ incubado em atmosfera de anaerobiose a $37^{\circ} \mathrm{C}$ por 24 horas. Colônias isoladas que apresentavam duplo halo de hemólise foram submetidas a provas bioquímicas, segundo Quinn et al. (1994), e processadas por uma técnica de PCR para os genes codificadores das toxinas alfa, beta, épsilon e iota de C. perfringens (Uzal

Recebido em 4 de julho de 2006

Aceito em 5 de julho de 2006

*Autor para correspondência (corresponding author)

E-mail: flobato@vet.ufmg.br 
et al., 1997). Uma fração do conteúdo intestinal foi centrifugada em refrigeração a $10.000 \times \mathrm{g}$ a $4^{\circ} \mathrm{C}$ por 30 minutos, o sobrenadante foi filtrado em membrana com poro de $0,22 \mu \mathrm{m}$, e a pesquisa de toxinas de $C$. perfringens foi feita pela técnica de soroneutralização em camundongos, segundo Tammemagy e Grant (1967).

Grande número de bastonetes curtos, grossos, não esporulados, Gram positivos únicos ou em cadeias, foram observados nos esfregaços da mucosa intestinal. Colônias branco-acinzentadas, umbilicadas, com um duplo halo de hemólise de aproximadamente $2 \mathrm{~mm}$ de diâmetro, sugestivas de C. perfringens foram observadas nas placas de ágar sangue. Colônias isoladas confirmaram tratar-se de C. perfringens pela caracterização bioquímica, e como sendo do tipo D pela PCR (Uzal et al., 1997). $\mathrm{Na}$ pesquisa de toxinas, os dois camundongos inoculados com o filtrado do conteúdo intestinal morreram em até 24 horas, os camundongos que receberam a mistura de filtrado mais antitoxina épsilon e filtrado aquecido a $100^{\circ} \mathrm{C}$ foram protegidos, permitindo tipificar a toxina como épsilon.

Com base no histórico, achados patológicos, microbiológicos e pela soroneutralização em camundongos, firmou-se o diagnóstico de enterotoxemia por C. perfringens tipo D.

A suspeita de enterotoxemia em bovinos adultos, principalmente nos quadros de morte súbita, tem sido relatada com freqüência por médicos veterinários, entretanto, o diagnóstico só é feito com base em sinais clínicos e, ocasionalmente, em achados de necropsia.

No Brasil, Silveira et al. (1995), relataram na região Centro-Oeste, casos de enterotoxemia em bovinos adultos. Entretanto, os autores apenas isolaram e tipificaram C. perfringens sem detecção direta da(s) toxina (s) envolvida (s). Outros relatos da ocorrência de enterotoxemia por $C$. perfringens, no país, foram feitos por Baldassi et al. (1995) e Colodel et al. (2003), ambos em caprinos. Baldassi et al. (1995) verificaram morte súbita em um rebanho caprino com base no isolamento de $C$. perfringens (sem tipificação) e na detecção de uma toxina termolábil letal, que não foi caracterizada. Colodel et al. (2003) descreveram cinco surtos de enterotoxemia em caprinos, com detecção direta da toxina épsilon produzida por $C$. perfringens tipo $\mathrm{D}$, pela técnica de soroneutralização em camundongos. Portanto, na espécie bovina, este constitui o primeiro diagnóstico no Brasil de enterotoxemia por $C$. perfringens tipo $\mathrm{D}$ com detecção da toxina épsilon em conteúdo intestinal. Desse modo, para um efetivo diagnóstico de enterotoxemia bovina, é imprescindível a detecção direta de toxinas em associação ao histórico, sinais clínicos, achados de necropsia, isolamento, caracterização bioquímica e tipificação do agente.

Palavras-chave: bovino, enterotoxemia, Clostridium perfringens tipo $\mathrm{D}$

\begin{abstract}
This report describes a case of bovine enterotoxaemia in Morro da Garça, Minas Gerais, Brazil. Clostridium perfringens type $D$ was isolated in pure culture and was characterized by biochemical reactions and PCR. By the mouse neutralization test, the presence of epsilon toxin from intestinal content was detected.
\end{abstract}

Keywords : cattle, enterotoxaemia, Clostridium perfringens type D

\section{AGRADECIMENTO}

Os autores agradecem ao Dr. Guilherme Rocha pelo envio do material para exame laboratorial.

\section{REFERÊNCIAS BIBLIOGRÁFICAS}

BALDASSI，L:; CALIL，E.M.B.; PORTUGAL, M.A.S.C. et al. Morte súbita de caprinos por enterotoxemia. Braz. J. Vet. Anim. Sci., v.32, p.109$113,1995$.
COLODEL, E.M.; DRIEMEIER, D.; SCHMITZ, M. et al. Enterotoxemia em caprinos no Rio Grande do Sul. Pesq. Vet. Bras., v.23, p.173-178, 2003.

KRIEK, N.P.J.; ODENDAAL, M.W; HUNTER, P. Clostridium perfringens type D enterotoxaemia. In: COETZER J.A.W.; THOMSON G.R ; TUSTIN R.C (Eds.). Infectious diseases of livestock with special reference to Southern Africa. Oxford: Oxford University, 1994. p.1315-1322. 
LOBATO, F.C.F.; MORO, E.; UMEHARA, O. et al. Avaliação da resposta de antitoxinas beta e épsilon de Clostridium perfringens induzidas em bovinos e coelhos por seis vacinas comerciais no Brasil. Arq. Bras. Med. Vet. Zootec., v.52, p.313$318,2000$.

MINAMI, J.; KATAYAMA, S.; MATSUSHITA, O. et al. Lambda-toxin of Clostridium perfringens activates the precursor of precursor of epsilon-toxin by realising its $\mathrm{N}$ - and C-terminal peptides. Microbiol. Immunol., v.41, p.527-535, 1997.

QUINN, P.J., CARTER, M.E., MARKEY, B. et al. Clostridium species. In: CLINICAL VETERINARY MICROBIOLOGY. London: Elsevier, 1994. p.191-208.
SIGURDARSON, S.; THORSTEINSSON, T. Sudden death of Icelandic dairy cattle. Vet. Rec., v.127, p.410, 1990.

SILVEIRA, D.; SOUZA, A.M.; MESQUITA, A.J. et al. Enterotoxemia em bovinos: uma enfermidade de importância emergente. Bol. Téc. Inf. RhodiaMérieux, v.2, p.1-4, 1995.

TAMMEMAGI, L.; GRANT, K.M. Vaccination in the control of bovine botulism in Queensland. Aust. Vet. J., v.43, p.368-372, 1967.

UZAL, F.A.; PLUMB, J.J.; BLACKALL, L.L. et al. PCR detection of Clostridium perfringens producing different toxins in faeces of goats. Lett. Appl. Microbiol., v.25, p.339-344, 1997. 